\title{
South African reforms slow to take shape...
}

Cape Town. South Africa's Minister of Arts, Culture, Science and Technology, Ben Ngubane, took the opportunity of the annual Zuckermann lecture, which he delivered in London last week, to elaborate on his plans for changing the country's science system (see below).

But his speech rang hollow among many scientists within the country itself, who are becoming increasingly exasperated with the apparent lack of progress in putting ideas into practice. "He is a polite recipient of invitations and applause, but has yet to make a direction-setting statement about science and technology," commented one senior research council official.

Unable to resist the English penchant for understatement, Ngubane - who describes himself an optimist - admitted that "there is much to be done" in developing of science and technology in South Africa. But concrete achievements so far seem to have been limited. For example, in his speech Ngubane claimed to have "initiated the process to form a National Advisory Committee on Science and Technology Policy", a body that he announced last February would be in place by June this year.

It remains unclear whether the apparent lack of progress reflects administrative fail- ures within his ministry, or Ngubane's own preoccupation with developments in his Inkatha Freedom Party. The party suffered further setbacks last week, with the decision of the attorney-general of Natal province to prosecute the party's deputy secretary-general, along with Magnus Malan, South Africa's former Minister of Defence, and ten former military officers, over the massacre of 13 civilians in 1987 by one of its alleged hit-squads.

Since the sacking of his former deputy minister, Winnie Mandela, in March, Ngubane has been deprived of the excuse that his ministry was beset by political problems. But delays continue. For example, having taken nine months to appoint Roger Jardine as his director-general - the senior civil servant post in the ministry - in February, an equivalent period has elapsed without appointments to two deputy director-general positions, one for arts and culture and one for science and technology.

Ministry officials nevertheless claim that considerable movement is taking place. For example, Ngubane used the Zuckermann lecture to commit his ministry to producing by December a green paper on science and technology, on which the scientific community will then be able to comment. A team of

\section{...as minister seeks to rally researchers}

London. South African researchers were urged last week by the cabinet minister responsible for science, Ben Ngubane, to support efforts not only to develop high technology but also to help secure the country's internal development.

Delivering the annual Zuckerman lecture in London - named after the late Lord (Solly)

Zuckerman, who

was himself

born in South

Africa, and who

was the chief

scientific advis-

er to successive

British govern-

ments in the

1960s - Ngu-

bane said the Ngubane: science must country's sci- help in reconstruction. ence and tech-

nology system had been distorted as a result of the "siege economy" that characterized the last 20 years of apartheid.

One of its current needs was to develop forms of technology that will make South Africa's relatively unskilled professions more self-sufficient. "New subsistence technology" was required in fields such as energy use and infrastructure development. Innovation and the deployment of talent was just as necessary in these fields as in more conventional areas of high technology, and were neither cheaper nor less complex. Indeed, Ngubane even admitted that working on such technologies creates what he described as "greater career risks for scientists".

Ngubane pointed out that much remained to be done to boost business confidence and accelerate economic growth in South Africa. But, while admitting that South Africa spends a much lower proportion of its resources on research and development than industrialized nations, he said the government's desire to pursue "sound fiscal policies" meant that "changes in our current spending patterns cannot be dramatic".

Ngubane also announced details of a new collaboration fund agreed earlier this year between the British and South African governments, and worth a total of $£ 600,000$ (US $\$ 960,000$ ) over a period of three years. The fund will in particular be used to support research projects and fellowships in the fields of agriculture/biotechnology, biomedicine and the environmental protection and use of natural resources. ten scientists - including representatives from the universities, science councils, the private sector and the ministry - had completed three weeks of deliberations on the paper two days previously.

An explicit acknowledgement that South Africa "devotes a large part of its scarce funds for science and technology to costly military and nuclear programmes" is among the terms of reference set for the task force by the ministry. The green paper will serve as a precursor to a white paper, to be tabled during next year's parliamentary session, which will guide the budgeting process for the 1997-98 financial year.

As far as the science budget for the 1996-97 financial year is concerned, the ministry has taken a small step towards reallocating funds between the research councils. Faced with a nominal increase of only 4.6 per cent in the science budget next year, the ministry decided to allocate 90 per cent of the total in the same proportions as it did this year.

But the presidents of the councils were invited to bid for the remaining 10 per cent by making presentations to a panel of civil servants, academics, parliamentarians and trade union officials, chaired by Jardine, on how well their respective programmes complied with the Reconstruction and Development Programme.

This process was completed last month, and recommendations have been submitted to the Ministerial Committee on Science and Technology (MCST), made up of the eight members of the cabinet whose ministries are responsible for administering research funds. This committee, chaired by Ngubane, meets next week, and has the final say in how the allocations are made.

But Ngubane has so far resisted demands to increase the transparency of the process by making the panel's recommendations public. This has left the council presidents free to lobby their ministers, who sit on the MCST, to intervene on their behalf.

Many scientists continue to argue that this system needs to be changed if funding is to go to the most deserving projects, and that increased transparency is an essential step in this direction (see Nature 362, 384; 1993). But so far, Ngubane appears to prefer sticking with the old system.

President Nelson Mandela, speaking last month at an international conference on cyclotrons and their applications in Cape Town, made a characteristically impassioned plea to scientists, engineers and academics "to resist the temptation to emigrate" as "the nation needs their collective creativity and ingenuity". So far, however, Mandela's well-intentioned move of setting up a separate ministry appears to many to have done little to secure the long-term viability of South African science.

Michael Cherry 